\title{
Republic of Lithuania: Financial Sector Assessment Program Update- Technical Note-Insolvency and Creditor Rights Assessment
}

This technical note on insolvency and creditor rights assessment for the Republic of Lithuania was prepared by a staff team of the International Monetary Fund and the World Bank as background documentation for the periodic consultation with the member country. It is based on the information available at the time it was completed on April 2008. The views expressed in this document are those of the staff team and do not necessarily reflect the views of the government of the Republic of Lithuania or the Executive Board of the IMF.

The policy of publication of staff reports and other documents by the IMF allows for the deletion of market-sensitive information.

Copies of this report are available to the public from

International Monetary Fund • Publication Services

700 19th Street, N.W. • Washington, D.C. 20431

Telephone: (202) 623-7430 • Telefax: (202) 623-7201

E-mail: publications@imf.org • Internet: http://www.imf.org

Price: $\$ 18.00$ a copy

\section{International Monetary Fund}

Washington, D.C. 



\title{
FinANCIAL SECtor ASSESSMENT PROGRAM UpDATE REPUBLIC OF LITHUANIA
}

\author{
INSOLVENCY AND CREDITOR RIGHTS ASSESSMENT \\ TECHNICAL NOTE \\ APRIL 2008
}

INTERNATIONAL MONETARY FUND MONETARY AND CAPITAL MARKETS DEPARTMENT
THE WORLD BANK FINANCIAL AND PRIVATE SECTOR DEVELOPMENT VICE PRESIDENCY Europe ANd CENTRAL ASIA REgion ViCE PRESIDENCY 


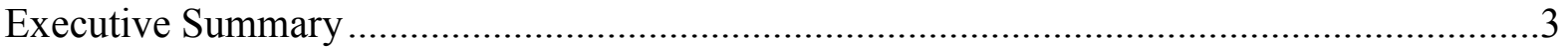

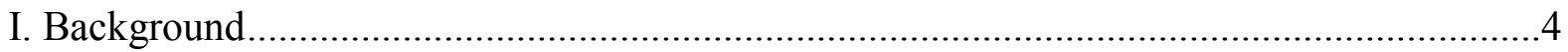

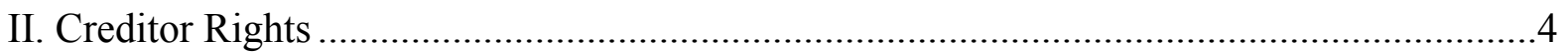

Legal framework for secured lending ..........................................................

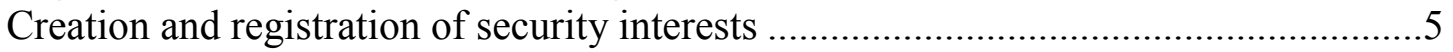

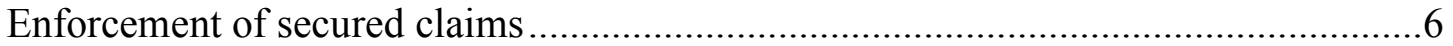

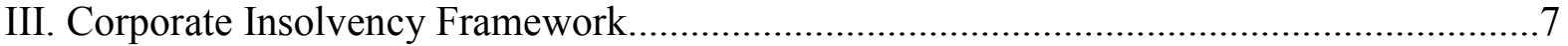

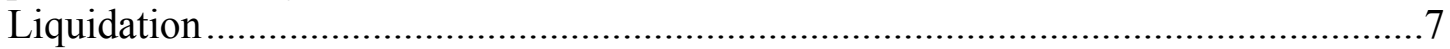

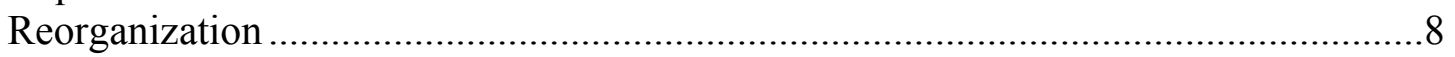

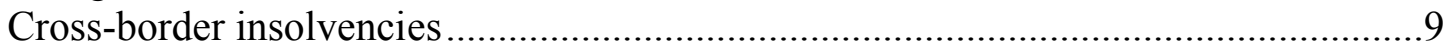

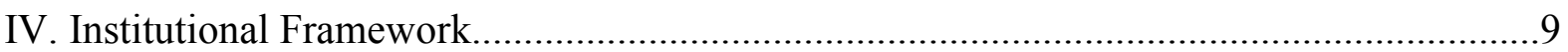

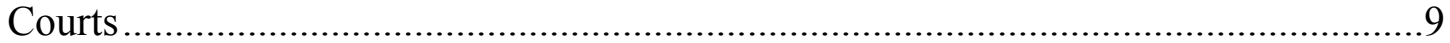

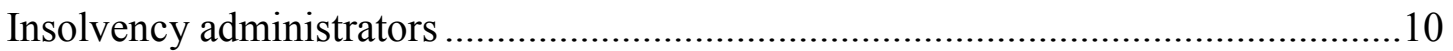

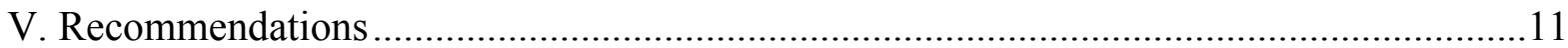

Tables

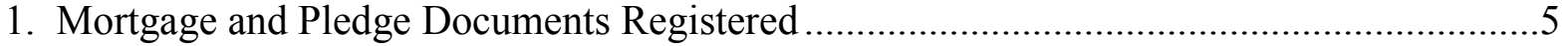

2. Bankruptcy Proceedings: Number of Cases ...................................................................... 7

3. Bankruptcy Proceedings: Average Duration of Cases......................................................8 


\section{EXECUTIVE SUMMARY}

Since the Insolvency and Creditor Rights (ICR) Report on Standards and Codes (ROSC) was conducted in 2001-02, Lithuania has made significant progress in the field of creditor rights legislation and related institutions. Under the current legal framework, the creation and registration of secured transactions is rather easy and affordable. Enforcement is also efficient, taking 4 to 7 months to recover a secured loan. The privatization of the bailiffs system has contributed to accelerating the recovery process and increasing the enforcement efficiency. In the area of corporate insolvency, the Enterprise Bankruptcy Law and the Law on Restructuring of Enterprises are generally consistent with international standards. The insolvency administration infrastructure is experiencing newly implemented reforms which are expected to improve the insolvency profession standards.

Notwithstanding this progress, a number of legal reforms could further improve the legal infrastructure for secured lending. These include (i) amending the Civil Code to allow the creation of security interests related to any or all of a debtor's obligations to a creditor, present or future, and in all types of assets and on a global basis; (ii) eliminating the concurrent functions of notaries and judges - mortgage judges should be exclusively dedicated to jurisdictional activities rather than to administrative tasks; and (iii) reviewing the current fee structure for executions, as the remuneration of the bailiffs ( 4 to 20 percent of the amount recovered) is generally considered too high by users of their services. In the insolvency field, making the simplified restructuring procedure more flexible would enhance the insolvency regime and facilitate reorganization. Enacting the UNCITRAL Model Law on Cross-border Insolvency would complement the legal infrastructure to dealing with international cases. Finally, the institutional framework for commercial disputes and insolvency proceedings is generally sound although specialization of some judges would improve the system's efficiency. 


\section{BACKGROUND ${ }^{1}$}

1. The Insolvency and Creditor Rights Report on the Observance of Standards and Codes (ICR ROSC), conducted in Lithuania in 2001-2002, found the legal environment for creditor rights and debt enforcement as being reasonably effective. ${ }^{2}$ However, the ICR ROSC also detected a number of weaknesses, including the following:

- The execution stage of collateral realization was quite inefficient.

- The insolvency system in general was considered rather weak and considerably fragmented because three different insolvency laws — entered into force in 1992, 1997, and 2001 - governed insolvency proceedings (according to initiation date of cases).

- Most insolvency proceedings were liquidation cases, averaging more than three years and yielding little benefit to creditors.

- There was no sufficient experience with the then newly enacted Enterprise Restructuring Law so as to properly assess its effectiveness.

2. A number of weaknesses also affected the institutional framework for creditor rights and insolvency. Court efficiency was stifled by a lack of specialization among judges. Low standards for licensing, as well as over-licensing, inadequate training and inconsistent performance of insolvency administrators, affected the implementation of the insolvency system.

3. This report does not constitute a full or formal reassessment of the initial ICR Assessment, but is instead a targeted review. To this end, several legal and institutional reforms, implemented in Lithuania since the ICR ROSC was conducted, are briefly evaluated.

\section{Creditor Rights}

\section{Legal framework for secured lending}

4. The Lithuanian legal framework for secured lending is now generally adequate. Under the Civil Code regime, mortgages and possessory and non-possessory pledges are broadly used (Table 1). Leasing contracts are frequently utilized to secure the acquisition of movable assets. Repossession of leased assets is almost always done without court intervention because defaulting debtors typically give the assets back to the leasing company. Notwithstanding this, if the debtor does not collaborate a simplified judicial proceeding is

\footnotetext{
${ }^{1}$ This report was prepared by Adolfo Rouillon, World Bank.

${ }^{2}$ See: http://www.worldbank.org/ifa/icr_ltu.pdf
} 
available for obtaining repossession. The law allows parties to agree upon reservation of title, but this mechanism is not very relevant in lending practices. Suppliers of goods occasionally use reservation of title clauses.

Table 1. Mortgage and Pledge Documents Registered (April 1, 1998 - September 1, 2007)

\begin{tabular}{|l|r|r|r|r|r|r|r|r|r|c|}
\hline & 1998 & 1999 & $\mathbf{2 0 0 0}$ & $\mathbf{2 0 0 1}$ & $\mathbf{2 0 0 2}$ & $\mathbf{2 0 0 3}$ & $\mathbf{2 0 0 4}$ & $\mathbf{2 0 0 5}$ & $\mathbf{2 0 0 6}$ & $\begin{array}{c}\text { Jan- } \\
\text { Sept } \\
\mathbf{2 0 0 7}\end{array}$ \\
\hline Mortgages & 12264 & 14537 & 11981 & 12563 & 15680 & 20545 & 25951 & 34368 & 39889 & 33320 \\
\hline Pledges & 2474 & 3464 & 2752 & 3607 & 5672 & 5680 & 6880 & 5816 & 6158 & 4235 \\
\hline Sub-Total & 14738 & 18001 & 14733 & 16170 & 21352 & 26225 & 32831 & 40184 & 46047 & 37555 \\
\hline \multicolumn{7}{|c|}{ TOTAL: 267,836 registered mortgages and pledges } \\
\hline
\end{tabular}

Source: Ministry of Justice, Central Mortgage Office.

5. The financial community is generally satisfied with the collateral legislation, but the system could be enhanced by introducing further flexibility. Key players underscore that a number of Civil Code provisions governing security interests are still too formalistic and somewhat rigid. For example, a creditor can not obtain a security interest in the universality of a debtor's assets; it is also impossible to take movable assets to pledge future obligations. Another practical restriction concerning pledges is the obligation to specifically describe every single item pledged. Thus, the legal infrastructure for secured lending could be further improved allowing the creation of: (i) pledges (over movable assets) related to any or all of a debtor's obligations to a creditor, present or future; and (ii) security interests on a global basis in all types of assets.

\section{Creation and registration of security interests}

6. The creation and registration of secured transactions is easy and affordable. The Central Mortgage Office - where both mortgages and pledges are recorded-is regarded as efficient and reliable. Mortgages are subsequently registered (by the mortgage judges) in the Real Estate and Land registers. All registers are computerized and publicly available. The total cost of creation and registration of mortgages and pledges is less than one percent of the loan amount, which is considered reasonable by financial institutions. ${ }^{3}$

\footnotetext{
${ }^{3}$ The maximum cost for creating and registering a mortgage or pledge is approximately US\$200 (notary and registry fees included).
} 
7. Eliminating the concurrent functions of notaries and judges would improve the overall efficiency of the system. The intervention of both a notary and a mortgage judge, required by law to create and register a mortgage, is duplicative and not efficient because:

- Reviewing of filings for accuracy and legality can be sufficiently performed by notaries; and

- Mortgage judges should be exclusively dedicated to jurisdictional activities (i.e. enforcement of secured claims) rather than to administrative tasks.

\section{Enforcement of secured claims}

8. The enforcement of secured claims is efficient. Enforcement of pledges and mortgages may be and usually is performed in a simplified manner, without dispute. ${ }^{4}$ Subject to claim by the creditor, if the borrower does not repay in 20-30 calendar days after judicial notification, the mortgage judge orders foreclosure through a bailiff. Mortgaged and pledged assets are then sold at public auction. The initial price for property to be sold shall be 80 percent of the valuation made by the bailiff or by an expert. If the property is not sold, a second auction shall be held discounting the initial price to 60 percent of the appraised value. If this auction also fails, the property may be transferred to the secured creditor. Users of the system are satisfied with the average recovery time of secured loans (4 to 7 months).

\section{Changes introduced to the bailiff system are regarded as successful. In the past,} bailiffs were civil servants. This system was changed in 2002, implementing a privatization of the bailiffs following the French model ("huissiers de justice"). Now bailiffs are independent professionals, licensed and removed by the Ministry of Justice. At present, there are approximately 140 bailiffs in Lithuania. ${ }^{5}$ The bailiff profession is self-governed by the Chamber of Bailiffs of Lithuania. The old system cost for the State was approximately 10 million litas per year, whereas the new system entails no cost to the national budget. In terms of overall efficacy, while the average enforcement efficiency of the old system was 5.5 percent, the new system's efficiency is six times higher according to the Ministry of Justice.

10. The bailiff fees are considered too high. Users of the bailiff services are satisfied with the reformed system although some concerns were received with respect to the

\footnotetext{
${ }^{4}$ The debtor can challenge the creditor's claim initiating a reverse lawsuit. In principle, this lawsuit does not stop the mortgage execution unless the debtor requests an injunction demonstrating prima facie the reasonability of his arguments. According to anecdotal evidence gathered in the field, debtors very rarely resort to the mentioned reverse lawsuit and injunction.

${ }^{5}$ The number of bailiffs is regulated by the State. A qualification examination is required to obtain a bailiff license. Most of the bailiff's procedural tasks can be (in fact, are) performed by assistants. The regulatory authority encourages competition between bailiffs, ensuring that in each territory at least two bailiffs are licensed and available.
} 
remuneration of the bailiffs (4 to 20 percent of the amount recovered), which is considered too high. The Ministry of Justice is undertaking a review of the current fee structure for executions - an initiative that is to be praised.

\section{Corporate Insolvency Framework}

\section{Liquidation}

11. Efficiency of bankruptcy proceedings is improving. The number of bankruptcy (liquidation) proceedings has been steady in the recent past (Table 2).

Table 2. Bankruptcy Proceedings: Number of Cases

\begin{tabular}{|l|c|c|c|c|c|c|c|c|c|}
\hline $\begin{array}{l}\text { Cases I } \\
\text { Year }\end{array}$ & $\begin{array}{c}\mathbf{1 9 9 3} \\
\mathbf{2 0 0 0}\end{array}$ & $\mathbf{2 0 0 1}$ & $\mathbf{2 0 0 2}$ & $\mathbf{2 0 0 3}$ & $\mathbf{2 0 0 4}$ & $\mathbf{2 0 0 5}$ & $\mathbf{2 0 0 6}$ & Total & $\begin{array}{l}\text { Per } \\
\text { cent }\end{array}$ \\
\hline Initiated & 1014 & 590 & 799 & 621 & 709 & 772 & 759 & 5264 & 100 \\
\hline Completed & 990 & 574 & 754 & 548 & 536 & 431 & 117 & 3948 & 75 \\
\hline Pending & 24 & 16 & 45 & 73 & 173 & 341 & 642 & 1316 & 25 \\
\hline
\end{tabular}

Source: Department of Enterprise Bankruptcy Management under the Ministry of Economy.

12. The fragmentation of the insolvency legal framework currently is almost irrelevant. ${ }^{6}$ Although the Bankruptcy Laws of 1992 and 1997 are still effective, the number of cases actually governed by these laws is now marginal. As of July 2007, 8 cases were dealt with under the law of 1992 and 14 cases under the law of 1997, whereas 1,207 cases were subject to the Bankruptcy Law of 2001. As no new cases can be initiated under the Bankruptcy Laws of 1992 and 1997, the fragmentation of the insolvency legal framework - trivial at present-will be fully overcome once the few remaining cases still dealt with under those laws had been completed.

13. The average duration of bankruptcy cases has improved, but not dramatically. While in 2001 a routine liquidation took more than 3 years, nowadays the average length of all bankruptcy proceedings typical duration is $\mathbf{1 . 8}$ years. This shortening is influenced by the introduction in 2003 of a "simplified bankruptcy procedure" - applicable to assetless enterprises - whose average duration is now 10.5 months. Not counting these simplified bankruptcies, 40 percent of cases take approximately 2 years, whereas 28 percent of cases still continue for nearly three years. Specialization of a group of judges, as indicated

\footnotetext{
${ }^{6}$ The ICR ROSC 2001-2002 considered that the insolvency environment was confusing because three versions of the enterprise liquidation law (of years 1992, 1997 and 2001) were simultaneously in effect - the two oldest versions being applicable to bankruptcy proceedings opened prior to 2001 and 1997.
} 
below, would be a key factor in order to further shorten the average duration of bankruptcy cases.

Table 3. Bankruptcy Proceedings: Average Duration of Cases (1993-2006)

\begin{tabular}{|c|c|}
\hline 10 percent & Up to 1 year \\
\hline 40 percent & 2 years \\
\hline 28 percent & 3 years \\
\hline 22 percent & More \\
\hline All Bankruptcy Proceedings & $\mathbf{1 . 8}$ years \\
\hline Simplified Bankruptcy Proceedings & 0.87 year \\
\hline
\end{tabular}

Source: Department of Enterprise Bankruptcy Management under the Ministry of Economy.

\section{Reorganization}

14. Restructuring proceedings are not frequently used yet. Upon commencement of bankruptcy (liquidation), restructuring of the company could take place through an amicable agreement signed by all creditors. Historically, this mechanism has been used in 26 cases. Before bankruptcy is adjudged, the insolvent enterprise may resort to restructuring proceedings governed by the Law on Restructuring of Enterprises, which is generally consistent with international standards. Notwithstanding this, since the enactment of the Law on Restructuring in 2001, only 36 cases have been filed, of which just 5 have been successfully completed. ${ }^{7}$

15. Making the simplified restructuring procedure more flexible would enhance the reorganization regime. The Law on Restructuring contemplates both a full in-court reorganization process and a simplified procedure akin to a prepackaged or abbreviated reorganization. The latter is a remarkable feature of the Lithuanian legal framework for corporate reorganization. Prepackaged or abbreviated reorganizations allow fast and costefficient processing of restructuring plans, which is always desirable but almost indispensable in times of systemic crisis where reorganization cases tend to increase significantly. A rigidity of the Lithuanian prepackaged or abbreviated reorganization system

\footnotetext{
${ }^{7}$ Though it is hard to determine a single cause of this restricted use of reorganization, key players interviewed mentioned several factors, including: (i) a majority of 75 percent of all liabilities - as required by law-is hard to obtain in most cases; (ii) debtors typically resort to reorganization too late; (iii) in the majority of reorganization cases, the debtor enterprise is no longer viable; (iv) too many formal restrictions established by the law.
} 
should, however, be pointed out: although under formal reorganization proceedings, restructuring plans can be adopted with the favorable voting of a majority of creditors, unanimity is required under the simplified procedure. In most cases, it is hard to obtain the consensus of all creditors, which explains why the current legal requirement of unanimous consent is a rigidity that makes the use of the otherwise advantageous simplified procedure difficult and rare.

16. Eliminating the unanimous consent required at present in abbreviated reorganizations will improve the environment for voluntary restructuring agreements and better equip the system to deal with larger numbers of business reorganizations. Given the existent culture of voluntary restructuring agreements (workouts) in Lithuanian banking practices, it would be very helpful to complement this practice with an abbreviated reorganization procedure through which workout agreements could be converted into restructuring plans even if unanimity is not obtained. Otherwise, voluntary restructurings without unanimous consent of creditors will not be able to be processed through an abbreviated reorganization. Those voluntary restructuring agreements will not bound those who opted for holding out, in this way creating a weakness in the system. On the contrary, if the court could cram down all creditors ${ }^{8}$, in the context of an abbreviated reorganization procedure, the system would be equipped with an invaluable mechanism for the prompt and cost-efficient resolution of numerous insolvencies. This significant improvement would just require an amendment to the Law on Restructuring so as to allow the utilization of the simplified procedure for restructuring in cases where the plan has been accepted by the same majority legally established for plans approved in full reorganization proceedings.

\section{Cross-border insolvencies}

17. Cross-border insolvencies within the European Union territory are now governed by the EU regulation. Since Lithuania joined the European Union, crossborder insolvencies involving EU countries are conducted based on the EU Council Regulation 1346/2000. Notwithstanding this, since the mentioned EU Regulation only governs cross-border insolvencies where the main place of business is within the EU, consideration should be given to adopting the UNCITRAL Model Law for Cross-border Insolvency, which would be applicable to cases involving foreign countries outside the EU.

\section{INSTITUTIONAL FRAMEWORK}

\section{Courts}

18. The Lithuanian institutional framework for insolvency proceedings is generally sound although specialization of a number of judges would enhance the system.

\footnotetext{
${ }^{8}$ Including the dissenting creditors, provided that a legally defined majority of creditors subscribed the restructuring agreement
} 
Insolvency cases are dealt with by judges that are also competent in all kind of civil and commercial matters. Users of the system point out that some judges do not have the level of training in complex commercial and economic topics usually needed in insolvency cases - in particular, in restructurings. In cities that are large commercial centers, specialization of a number of existent judges would significantly enhance the overall efficiency of insolvency proceedings. Necessary training of judges and judicial staff as well as on-the-ground resources should be provided to ensuring that specialized judges or courts produce measurable improvement in the handling of insolvency cases. The specialization of some judges would also improve their capacity to deal with cases linked to the increasingly complex financial transactions and issues arising in Lithuania's financial sector.

\section{Insolvency administrators}

\section{The insolvency administration infrastructure is experiencing newly implemented}

reforms. New Rules of Entitlement and Rules of Control of Bankruptcy Administrators were approved in 2006. Regulations for the Commission for Certification of Bankruptcy and Restructuring Administrators were passed in 2007. Enjoying a university degree in law or economics is now mandatory to obtain a license. Experience, training and good conduct are also qualification criteria. A Code of Ethics applicable to insolvency administrators has been approved by the Ministry of Economy. The recent reforms introduced to licensing, supervision and performance evaluation of insolvency administrators, as well as certification programs under preparation, are expected to improve the insolvency profession standards.

\section{The number of licensed and practicing insolvency administrators seems}

adequate. During the period 1997-2006 the right to provide services of bankruptcy administration was granted to 800 natural persons and 126 legal entities. From 2001 to 2006, 80 natural persons and 24 legal entities were entitled to provide services in restructuring administration. At the end of 2006, there were approximately: (i) 284 individuals and 95 legal entities licensed to act as bankruptcy administrators, and (ii) 31 individuals and 19 legal entities licensed to provide services in restructuring cases. Actually, the number of practicing administrators would be lower. Licenses should now be revalidated every three years. After a second revalidation and with approval of the Commission for Certification of Bankruptcy and Restructuring Administrators, an insolvency administrator may keep the license for the next ten years. During 2007 a few licenses were canceled. Continued education is provided by the professional associations of insolvency administrators - the National Association of Bankruptcy Administrators (21 members) and the National Association of Business Administrators (110 members). Courses are held every month with an average participation of 30-40 attendees. Participating in training courses, at least 32 hours per year, is mandatory for all licensed administrators. 


\section{RECOMMENDATIONS}

21. Notwithstanding the aforementioned progress, a number of legal reforms could further improve the legal and institutional infrastructure for secured lending and

insolvency. The authorities should consider the advantages of the following recommended mid-term reforms:

- Amending the Civil Code to allow the simple creation of: (i) pledges (over movable assets) related to any or all of a debtor's obligations to a creditor, present or future, and, (ii) security interests on a global basis in all types of assets.

- Eliminating the concurrent functions currently performed by notaries and judges at creation and registration of secured transactions.

- Reviewing the current fee structure for remuneration of bailiffs at executions;

- Making the simplified restructuring procedure more flexible, allowing judicial approval of reorganization plans approved by a legally established majority of creditors even if unanimous consent of creditors had not been obtained;

- Enacting the UNCITRAL Model Law on Cross-border Insolvency; and,

- Specializing and training of a number of judges to deal with insolvency proceedings and complex commercial/financial disputes. 